\title{
Maternal Mortality in Klaten Regency (Determinant Factors Analysis)
}

\author{
Arfan Syahfani Sesunan, Supriyadi Hari Respati, Sri Sulistyowati
}

Department Obstetrics and Gynecology, Faculty of Medicine, Universitas Sebelas Maret/ Dr. Moewardi Hospital, Surakarta

\section{ABSTRACT}

Background: Failure in reducing maternal mortality has become one of the world's health problems. Indonesia ranks third on the list of the highest MMR in ASEAN countries. The incidence of maternal mortality is caused by several factors, including reproductive status, obstetric complications, health services, and socioeconomic conditions.

Subjects and Method: This study was an analytic observational study using a case-controlled study design. The study subjects were selected by using fixed random sampling with a total sample of 129 people consisting of 43 cases of maternal mortality in Klaten Regency and 86 controls. Maternal mortality data were taken in Klaten Regency from 2017 to 2019. The independent variables were pregnancy complications, delivery complications, postpartum complications, age of pregnant women, pregnancy spacing, parity, delay in making decisions, referral delay due to inadequate transportations, delay in handling by health workers, the quantity of ANC, maternal education, maternal occupation, and family income. The dependent variable was maternal mortality in Klaten Regency. The data collection of this study used a questionnaire. Data analysis was carried out by univariate, bivariate, and multivariate methods using the chi-square test. Path analysis and descriptive analysis were performed and presented in narrative form.
Results: The delay in making decisions increases with family income below the city minimum wage $(\mathrm{OR}=1.69 ; \mathrm{p}=0.09)$. Referral delay increases with family income below the minimum wage $(\mathrm{OR}=1.73 ; \mathrm{p}=0.08)$. Maternal mortality increased with delay in decision making $\left(\mathrm{OR}=5\right.$ - $^{-}$ $28 ; \mathrm{p}=0.00$ ), quantity of ANC (OR: 2.37; p: o.02), income (OR: 3.92; p: o.0o), delivery complications (OR: 2.71; p: o.01) ), postpartum complications (OR: 6.33; p: o.0o). Maternal mortality was indirectly affected by income.

Conclusion: Pregnancy complications, delivery complications, postpartum complications, ANC examinations, delay in making decisions, delay in reaching the referral place, maternal education and income are associated with an increased risk of maternal mortality. While, maternal age, parity, pregnancy spacing, delay in handling by health workers, and maternal occupation have no significant association with maternal mortality.

Keywords: Determinant Factors, Maternal Mortality, Klaten Regency

\section{Correspondence:}

Arfan Syahfani Sesunan. Department Obstetrics and Gynecology, Faculty of Medicine, Universitas Sebelas Maret/ Dr. Moewardi Hospital, Surakarta, Central Java. Mobile: o8127949433. Email: arfansyahfani.s@gmail.com.

Cite this as:

Sesunan AS, Respati SH, Sulistyowati S (2020). Maternal Mortality in Klaten Regency (Determinant Factors Analysis). J Matern Child Health. 06(02): 183-196. https://doi.org/10.26911/thejmch.2021.06.02.06.

(c) (F) (-) Journal of Maternal and Child Health is licensed under a Creative Commons Attribution-Non Commercial-Share Alike 4.o International License.

\section{BACKGROUND}

Maternal health is the physical well-being of women during pregnancy, delivery, and postpartum that has been a major concern of several international conferences since the 1980s (WHO, 2011; Olonade, 2019; Smith and Rodriguez, 2016). Maternal mortality is a primary constituent of maternal health. WHO has defined maternal mortality as the death of a woman while pregnant or within 42 days of pregnancy termination, regardless of the duration and place of pregnancy, from 
any cause related to or exacerbated by pregnancy or its management, but not from the accident and incidental causes. The growing concern about improving reproductive health at the global level has created a demand for research, especially maternal health (WHO, 2019 a).

Every day in 2017, approximately 810 women died related to pregnancy and delivery. This means that maternal mortality is very high. About 295,000 women died during and after pregnancy and delivery in 2017. $94 \%$ of all maternal mortality occurred in low and middle income countries (WHO, 2019 b). It is estimated that every minute, 16,000 women in the world die due to pregnancy complications (SK et al., 2019). According to other statistics, the maternal mortality rate is around 216 per 100,00o live births (WHO, 2019 c). One of the Millennium development goals is the improvement of maternal health (MDG5). It aims to reduce maternal mortality rates by $75 \%$ between 1990 and 2015 and universal access to reproductive health by 2015 (Hogan et al., 2010). Globally it is reported that maternal mortality between 2000 and 2017 has decreased by $38 \%$ worldwide (WHO, 2019b). Failure to reduce maternal mortality has become one of the world's health problems (Ahmed and Fullerton, 2019).

From the maternal mortality rate (MMR) data in 2017, it is known that Indonesia ranks third in the list of the highest MMR in ASEAN countries at 177 per 100,000. However, the trend has decreased so that it still does not meet the Sustainable Development Goals (SDGs) target of $<70$ per 100 , 000 live births by 2030 (WHO, 2019a).

According to data from the Central Java Province Health Profile, in 2017, there was data on maternal mortality of 475 cases or 88.05 per 100,00o live births. In 2018 maternal mortality decreased significantly, as many as 421 cases or 78.60 per 100,000 live births
(Health Profile Central Java, 2018). Klaten Regency, as part of Central Java Province in 2017, contributed 18 maternal mortality. Then, in 2018 there were 13 maternal deaths (Central Java Health Profile, 2018).

The cause of the high maternal mortality in Klaten Regency is due to several factors, namely: distant factors (socioeconomic, cultural) which include; occupation, income level, intermediate factors (health and reproductive behavior, access to health services), and imminent factors (obstetric complications).

Various studies on contributing factors to maternal mortality have been carried out, including Olonade's study, which finds that apart from medical causes (direct and indirect), maternal death is caused by certain socio-cultural and socioeconomic factors (Olonade et al., 2014). A study conducted by Sk et al., found that three delays affect maternal mortality, namely the prevalence of delay in making decisions by $48.6 \%$, the prevalence of delay in reaching health facilities by $33.8 \%$, and the prevalence of delay in getting treatment by health workers by $18.9 \%$ (Sk et al., 2019).

Age, home characteristics, and distance to health care are risk factors for maternal mortality (Cameron et al., 2019). Maternal mortality is more likely caused by pregnancy complications, delivery complications, and disease history that also become the risk factors of maternal mortality (Aeni, 2013). Maternal mortality is caused by complications, nutritional status, parity, age of pregnant women, ANC examination, family planning history, and income.

Based on the data above, it can be seen that most maternal deaths are caused by several factors related to maternal factors, reproductive status, obstetric complications, health services, and socioeconomic conditions. Therefore, researchers are interested in modifying and developing a previous study 
on the determinants affecting maternal mortality. The object of the study was carried out in Klaten Regency.

\section{SUBJECTS AND METHOD}

\section{Study Design}

This study was conducted in Klaten Regency. Data collection for maternal deaths was taken at the Klaten District Office, and control data were taken at the health centers where there were maternal incidents from 2017 to 2019.

\section{Population and Sample}

Case subjects were taken from maternal mortality data available at the Klaten District Health Office as many as 43 recent maternal death cases whose date of death was close to the study's start date. Maternal mortality used was that occurred in 2017, 2018, and 2019. The study subjects were selected by fixed random sampling. This technique used all mothers who died as cases and mothers who live (until the puerperium) as controls.

\section{Study Variables}

The dependent variable was maternal mortality in Klaten Regency. The independent variables were pregnancy complications, delivery complications, postpartum complications, age of pregnant women, pregnancy spacing, parity, delay in making decisions, delay in referrals due to transportation, delay in handling by health workers, the quantity of ANC, maternal education, maternal occupation, and family income.

\section{Operational Definition of Variables}

Maternal mortality was a death that occurs in the mother during pregnancy and or within 42 days after the end of pregnancy, caused by pregnancy, delivery, and the postpartum complications or its handling, illnesses suffered before or during pregnancy, aggravated by pregnancy and not death by accident or coincidence.

Pregnancy complications occur during the last pregnancy, including bleeding, preeclampsia/eclampsia, and infection. Indicators of pregnancy complications were based on research.

Delivery complications occur during the delivery process in the form of bleeding, prolonged labor, infection, preeclampsia/eclampsia, shock, placental abnormalities, and location abnormalities that occur before or during delivery.

Postpartum complications occur within 42 days after the end of pregnancy, in the form of puerperal infection, preeclampsia/eclampsia, and bleeding during the puerperium. Maternal age was the age of the mother at the last pregnancy. Parity was the number of deliveries the mother has experienced. The pregnancy interval was the period between the previous pregnancy and the last pregnancy.

The ANC quantity was a pregnancy check performed to check the condition of the mother and her fetus periodically, followed by correcting any deviations found.

Maternal education was the last formal education a mother had received until the last delivery.

Employment status was an activity other than being a housewife during the period of pregnancy to delivery.

Family income was the amount of income received each month to meet the main family's needs as measured in rupiah.

\section{Data Analysis}

Bivariate analysis was carried out using the Chi-Square test. Multivariate analysis was carried out using path analysis at a significance level of $95 \%$.

\section{Research Ethics}

This research has been complemented by consent, anonymity, and was confidential. Ethical approval had been obtained from the Health Research Commission at Dr. Moewardi Hospital, Surakarta, Central Java, with number: 1389 / XII / HREC / 2019. 


\section{RESULTS}

1. Univariate analysis

Based on Table 1, it can be seen that the proportion of maternal mortality was mostly due to pregnancy complications as many as 30 people (69.8\%), delivery complications 21 Table 1. Univariate Analysis

\begin{tabular}{|c|c|c|c|c|}
\hline \multirow{2}{*}{ Variable } & \multicolumn{2}{|c|}{$\operatorname{Case}(n=43)$} & \multicolumn{2}{|c|}{ Control(n=86) } \\
\hline & $\mathbf{N}$ & $\%$ & $\mathbf{N}$ & $\%$ \\
\hline \multicolumn{5}{|l|}{ Pregnancy Complications } \\
\hline Yes & 30 & 69.8 & 20 & 23.3 \\
\hline No & 13 & 30.2 & 66 & 76.7 \\
\hline \multicolumn{5}{|l|}{ Delivery Complications } \\
\hline Yes & 21 & 48.8 & 12 & 14.0 \\
\hline No & 22 & 51.2 & 74 & 86.0 \\
\hline \multicolumn{5}{|l|}{ Postpartum complications } \\
\hline Yes & 22 & 51.2 & 5 & 5.8 \\
\hline No & 21 & 48.8 & 81 & 94.2 \\
\hline \multicolumn{5}{|l|}{ Delay in making decisions } \\
\hline Delayed & 16 & 37.2 & 1 & 1.2 \\
\hline Not delayed & 27 & 62.8 & 85 & 98.8 \\
\hline \multicolumn{5}{|l|}{ Delay in the referral process } \\
\hline Delayed & 3 & 7.0 & - & - \\
\hline Not delayed & 40 & 93.0 & 86 & 100 \\
\hline \multicolumn{5}{|l|}{ Delay in obtaining service } \\
\hline Delayed & 1 & 2.3 & - & - \\
\hline Not delayed & 42 & 97.7 & 86 & 100 \\
\hline \multicolumn{5}{|l|}{ Maternal Age } \\
\hline$<20$ years or $>34$ years & 17 & 39.5 & 37 & 43.0 \\
\hline $20-34$ years & 26 & 60.5 & 49 & 57.0 \\
\hline \multicolumn{5}{|l|}{ Parity } \\
\hline$<1$ child or $\geq 4$ children & 3 & 7.0 & 2 & 2.3 \\
\hline$\geq 1$ child & 40 & 93.0 & 84 & 97.7 \\
\hline \multicolumn{5}{|l|}{ Pregnancy spacing } \\
\hline$<2$ years & 5 & 11.6 & 7 & 8.1 \\
\hline \multicolumn{5}{|l|}{ ANC } \\
\hline$<4$ times & 4 & 9.3 & 1 & 1.2 \\
\hline$\geq 4$ times & 39 & 90.7 & 85 & 98.8 \\
\hline \multicolumn{5}{|l|}{ Education } \\
\hline Low (Elementary School-Senior High School) & 41 & $95 \cdot 3$ & 68 & 79.1 \\
\hline High (University) & 2 & 4.7 & 18 & 209 \\
\hline \multicolumn{5}{|l|}{ Occupation } \\
\hline Employed & 15 & 34.9 & 26 & 30.2 \\
\hline & 28 & 65.1 & 60 & 69.8 \\
\hline \multicolumn{5}{|l|}{ Family income } \\
\hline$<$ minimum wage $(\operatorname{Rp} 1,795,061)$ & 23 & 53.5 & 15 & 17.4 \\
\hline$\geq$ minimum wage $(\operatorname{Rp} 1,795,061)$ & 20 & 46.5 & 71 & 82.6 \\
\hline
\end{tabular}

It was known that the mother who died because of delay in making decisions 16 people (48.8\%), postpartum complications 22 people (51.2\%). Likewise in the control group, 20 respondents (23.3\%) experienced pregnancy complications, 12 (14.0\%) delivery complications, and 5 postpartum complications $(5.8 \%)$. people (37.2\%), delay to the referral point 3 people (7.0\%), and delay in obtaining ser- 
vices one person (2.3\%). While in the control group, one person (1.2\%) was late in making decisions, but there was no delay in the referral process and no delays in obtaining services. The highest proportion of maternal mortality aged 20-34 years was 26 people (60.5\%), parity $>1$ time was 40 people (93.0\%), pregnancy interval $>2$ years was 38 people (88.4\%), ANC quantity $>4$ times 39 people (90.7\%). Likewise, in the control group, the majority of mothers aged 20-34 years were 49 people (57.0\%), parity $>1$ times 84 people $(97.7 \%)$, gestation interval $>2$ years 79 people (91.9\%), and the quantity of ANC $>4$ times 85 people (98.8\%). The proportion of maternal mortality was mostly on mothers with low education as many as 41 people (95.3\%), housewives 28 people (65.1\%), and mothers with a salary below the Klaten minimum wage were 23 people (53.5\%). Likewise, in the control group, 68 people with low education (79.1\%), 6o housewives (69.8\%), and 71 people with salaries above the minimum wage in Klaten (82.6\%).

\section{The result of bivariate analysis}

The results of the bivariate analysis showed that pregnancy complications $(\mathrm{OR}=7.61$; $95 \% \mathrm{CI}=3.35$ to $17.3 ; \mathrm{p}=0.001)$, delivery complications $(\mathrm{OR}=5.88 ; 95 \% \mathrm{CI}=2.5$ to $13.8 ; \mathrm{p}=0.001)$ and postpartum complications $(\mathrm{OR}=16.97 ; 95 \% \mathrm{CI}=5.74$ to $50.17 ; \mathrm{p}=$ o.001) were associated with maternal mortality.

Tabel 2. Factors Related to Obstetric Complications in Klaten Regency

\begin{tabular}{lccccccc}
\hline \multirow{2}{*}{ Obstetric Complications } & \multicolumn{2}{c}{$\begin{array}{c}\text { Case } \\
(\mathbf{n}=\mathbf{4 3})\end{array}$} & \multicolumn{2}{c}{$\begin{array}{c}\text { Control } \\
(\mathbf{n}=\mathbf{8 6})\end{array}$} & \multirow{2}{*}{ OR } & $\mathbf{9 5 \%} \mathbf{C I}$ & \multirow{2}{*}{$\mathbf{p}$} \\
\cline { 2 - 5 } & $\mathbf{N}$ & $\mathbf{\%}$ & $\mathbf{N}$ & $\mathbf{\%}$ & & & \\
\hline Pregnancy Complications & & & & & & & \\
Yes & 30 & 60.0 & 20 & 40.0 & 7.615 & $3.351-17.306$ & $<0.001$ \\
No & 13 & 16.5 & 66 & 83.5 & & & \\
Delivery Complications & & & & & & & \\
Yes & 21 & 63.6 & 12 & 36.4 & 5.886 & $2.506-13.829$ & $<0.001$ \\
No & 22 & 22.9 & 74 & 77.1 & & & \\
Postpartum Complications & & & & & & & \\
Yes & 22 & 81.5 & 5 & 18.5 & 16.971 & $5.745-50.134$ & $<0.001$ \\
No & 21 & 20.6 & 81 & 79.4 & & & \\
\hline
\end{tabular}

Maternal age between 20-34 years $(\mathrm{OR}=0.86 ; 95 \% \mathrm{CI}=0.41$ to $1.82 ; \mathrm{p}=0.705)$, 2-3 times parity $(\mathrm{OR}=3.15 ; 95 \% \mathrm{CI}=0.5$ to 19.6; $\mathrm{p}=0.197)$, and birth interval $>2$ years $(\mathrm{OR}=1.48 ; 95 \% \mathrm{CI}=0.44$ to $4.98 ; \mathrm{p}=0.52)$ decreased the risk of maternal mortality, but this was not statistically significant. Meanwhile, the total number of ANC visits $\geq 4$ times had a significant effect on reducing maternal mortality (OR = 8.71; 95\% CI: 0.94 to $80.57 ; \mathrm{p}=0.024)$.

The results of the bivariate analysis also showed that there was a statistical significance between delay in decision making $(\mathrm{OR}=$
$50.37 ; 95 \% \mathrm{CI}=6.38$ to $397.65 ; \mathrm{p}<0.001)$ and delay in referral $(\mathrm{p}=0.013)$ with maternal mortality. Meanwhile, delays in obtaining services did not significantly affect maternal mortality $(\mathrm{p}=0.156)$.

From the socio-economic factors, this study showed that education $(\mathrm{OR}=5.426$; $95 \% \mathrm{CI}=1.19$ to $24.59 ; \mathrm{p}=0.016)$ and family income $(\mathrm{OR}=5.44 ; 95 \% \mathrm{CI}=2.4$ to $12.33 ; \mathrm{p}$ $<0.001)$. had a significant effect on maternal mortality. Meanwhile, occupation had no association with maternal mortality ( $\mathrm{OR}=$ 1.23; $95 \% \mathrm{CI}=0.56$ to $1.9 ; \mathrm{p}=0.593$ ). 
Sesunan et al./ Maternal Mortality in Klaten Regency

Table 3. High-Risk Pregnancy Factors

\begin{tabular}{|c|c|c|c|c|c|c|c|}
\hline & \multicolumn{2}{|c|}{$\begin{array}{c}\text { Case } \\
(n=43)\end{array}$} & \multicolumn{2}{|c|}{$\begin{array}{c}\text { Control } \\
(n=86)\end{array}$} & \multirow[t]{2}{*}{$\mathbf{O R}$} & \multirow[t]{2}{*}{$95 \% \mathrm{CI}$} & \multirow[t]{2}{*}{$\mathbf{p}$} \\
\hline & $\mathbf{N}$ & $\%$ & $\mathbf{N}$ & $\%$ & & & \\
\hline \multicolumn{8}{|l|}{ Maternal Age } \\
\hline$<20$ or $>34$ years & 17 & 31.5 & 37 & 68.5 & 0.866 & $0.411-1.825$ & 0.705 \\
\hline $\begin{array}{l}20-34 \text { years } \\
\text { Parity }\end{array}$ & 26 & 34.7 & 49 & $65 \cdot 3$ & & & \\
\hline $\begin{array}{l}\leq 1 \text { child or }>4 \text { child } \\
2-3 \text { child }\end{array}$ & $\begin{array}{c}3 \\
40\end{array}$ & $\begin{array}{l}60.0 \\
32.3\end{array}$ & $\begin{array}{c}2 \\
84\end{array}$ & $\begin{array}{l}40.0 \\
67.7\end{array}$ & 3.150 & $0.506-19.605$ & 0.197 \\
\hline Birth Interval & & & & & & & \\
\hline$<2$ years & 5 & 41,7 & 7 & 58.3 & 1.485 & $0.442-4.985$ & 0.520 \\
\hline $\begin{array}{l}\geq 2 \text { years } \\
\text { ANC }\end{array}$ & 38 & 32.5 & 79 & 67.5 & & & \\
\hline $\begin{array}{l}<4 \text { times } \\
\geq 4 \text { times }\end{array}$ & $\begin{array}{c}4 \\
39\end{array}$ & $\begin{array}{l}80.0 \\
31.5\end{array}$ & $\begin{array}{c}1 \\
85\end{array}$ & $\begin{array}{l}20.0 \\
68.5\end{array}$ & 8.718 & $0.943-80.579$ & 0.024 \\
\hline
\end{tabular}

Table 4. Factors related to Health Services in Klaten Regency

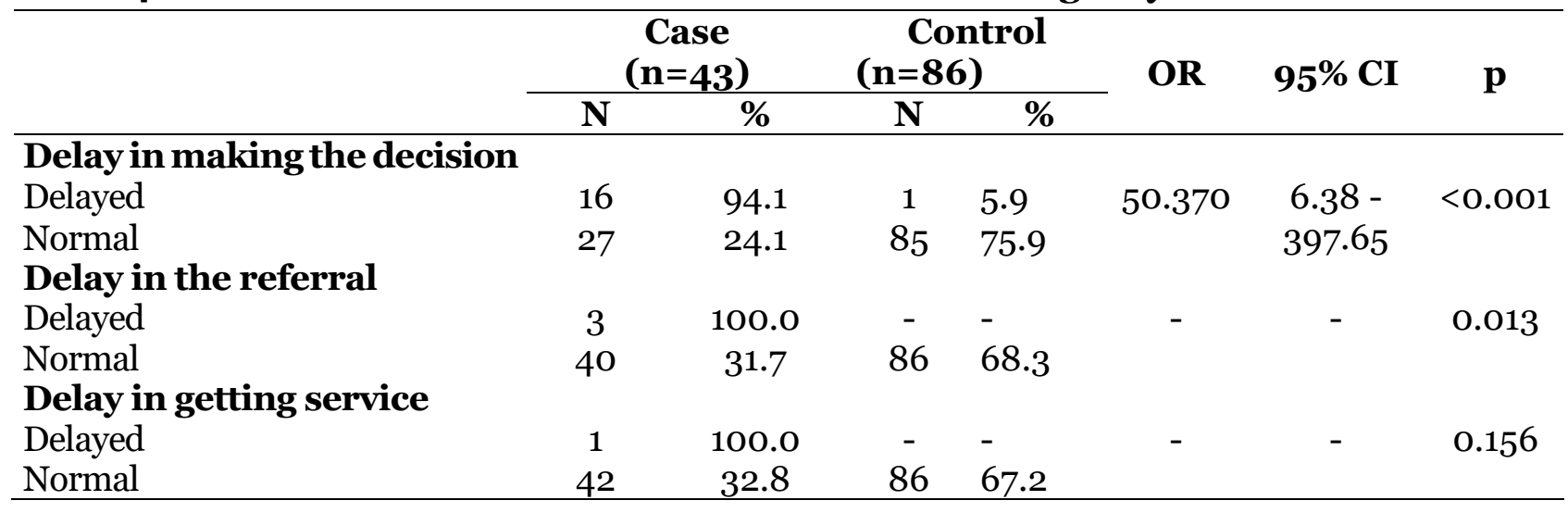

Table 5. Socioeconomic factors related to Maternal Mortality in Klaten Regency

\begin{tabular}{|c|c|c|c|c|c|c|c|}
\hline & \multicolumn{2}{|c|}{$\begin{array}{c}\text { Case } \\
(n=43)\end{array}$} & \multicolumn{2}{|c|}{$\begin{array}{c}\text { Control } \\
(n=86)\end{array}$} & \multirow[t]{2}{*}{ OR } & \multirow[t]{2}{*}{$95 \% \mathrm{CI}$} & \multirow[t]{2}{*}{$\mathbf{p}$} \\
\hline & $\mathbf{N}$ & $\%$ & $\mathbf{N}$ & $\%$ & & & \\
\hline \multicolumn{8}{|l|}{ Education } \\
\hline Low ( $<$ Senior high school) & 41 & 37.6 & 68 & 62.4 & 5.43 & \multirow{2}{*}{$1.20-24.60$} & \multirow[t]{2}{*}{0.016} \\
\hline High (University) & 2 & 10.0 & 18 & 90.0 & & & \\
\hline \multicolumn{8}{|l|}{ Occupation } \\
\hline Employed & 15 & 36.6 & 26 & 63.4 & 1.24 & \multirow[b]{2}{*}{$0.57-1.91$} & \multirow[t]{2}{*}{0.593} \\
\hline Unemployed & 28 & 31.8 & 60 & 68.2 & & & \\
\hline \multicolumn{8}{|l|}{ Income } \\
\hline Low $<$ minimum wage & 23 & 60.5 & 15 & 39.5 & 5.44 & \multirow{2}{*}{$2.40-12.34$} & \multirow[t]{2}{*}{$<0.001$} \\
\hline High $\geq$ minimum wage & 20 & 22.0 & 71 & 78.0 & & & \\
\hline
\end{tabular}

\section{Path Analysis}

Path analysis was carried out to determine how much all risk factors simultaneously contributed to maternal death incidence. The results of the path analysis model can be seen in Figure 1. 


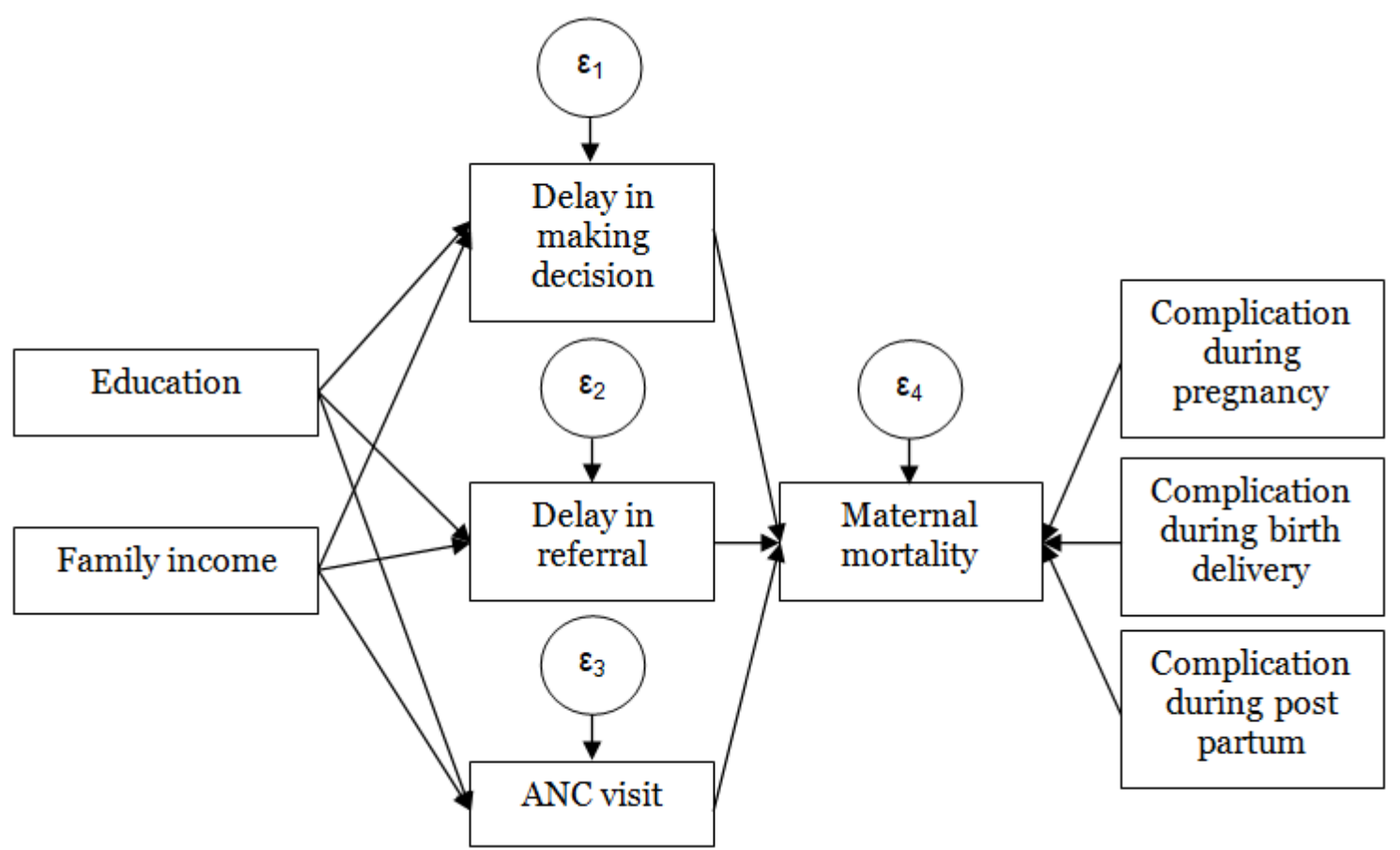

Figure 1. Path Analysis Model with Estimated Values

Table 5. Path Analysis

\begin{tabular}{|c|c|c|c|c|c|}
\hline $\begin{array}{c}\text { Dependent } \\
\text { Variable }\end{array}$ & & Independent Variable & $\mathbf{O R}$ & 95\% CI & $\mathbf{p}$ \\
\hline \multicolumn{6}{|l|}{ Direct effect } \\
\hline Maternal & $\leftarrow$ & Late in making decisions & 5.28 & $0.29-0.63$ & $<0.001$ \\
\hline \multirow[t]{7}{*}{ Mortality } & $\leftarrow$ & Delay in the referral & 0.88 & $-0.21-0.55$ & 0.380 \\
\hline & $\leftarrow$ & ANC quantity & 2.37 & $0.06-0.64$ & 0.020 \\
\hline & $\leftarrow$ & Education & 0.74 & $-0.10-0.21$ & 0.460 \\
\hline & $\leftarrow$ & Family income & 3.92 & $0.12-0.37$ & $<0.001$ \\
\hline & $\leftarrow$ & Pregnancy complications & 0.07 & $-0.11-0.12$ & 0.950 \\
\hline & $\leftarrow$ & Delivery complications & 2.71 & $0.05-0.31$ & $<0.001$ \\
\hline & $\leftarrow$ & Postpartum complications & 6.33 & $0.31-0.59$ & $<0.001$ \\
\hline \multicolumn{6}{|l|}{ Indirect effect } \\
\hline Delay in making & & Education & 0.07 & $-0.16-0.17$ & 0.950 \\
\hline decisions & & Family Income & 1.69 & $-0.02-0.24$ & 0.090 \\
\hline Delay in the & $\leftarrow$ & Education & -1.25 & $-0.12-0.03$ & 0.210 \\
\hline referral & $\leftarrow$ & Family Income & 1.73 & $-0.01-0.11$ & 0.080 \\
\hline \multirow[t]{2}{*}{ ANC Quantity } & $\leftarrow$ & Education & 0.65 & $-0.06-0.12$ & 0.520 \\
\hline & $\leftarrow$ & Family Income & 1.37 & $-0.02-0.13$ & 0.170 \\
\hline Maternal & $\leftarrow$ & Education & 0.13 & $-0.080-0,091$ & 0.900 \\
\hline Mortality & $\leftarrow$ & Family Income & 2.14 & $0.006-0,147$ & 0.030 \\
\hline
\end{tabular}

Table 5 shows that on a direct association, delay in making decision had a risk of maternal mortality by 5.28 times $(\mathrm{OR}=5.28$; $95 \% \mathrm{CI}=$ 0.29 to $0.63 ; \mathrm{p}<0.001)$, the quantity of $\mathrm{ANC}$ had a risk of maternal mortality by 2.37 times $(\mathrm{OR}=2.37 ; 95 \% \mathrm{CI}=0.06$ to $0.64 ; \mathrm{p}=0.018)$, family income had a risk of maternal death by 3.92 times $(\mathrm{OR}=3.92 ; 95 \% \mathrm{CI}=0.12$ to 0.37 ; $\mathrm{p}<0.001)$, delivery complications have a risk of maternal mortality by 2.71 times $(\mathrm{OR}=$ $2.71 ; 95 \% \mathrm{CI}=0.05$ to $0.31 ; \mathrm{p}<0.001)$, postpartum complications have a risk of maternal 
mortality by 3.92 times $(\mathrm{OR}=6.33$; $95 \% \mathrm{CI}=$ 0.31 to $0.59 ; \mathrm{p}<0.001)$. The indirect association between income variables and maternal mortality has 2 a risk of maternal mortality by 14 times $(\mathrm{OR}=2.14 ; 95 \% \mathrm{CI}=0.01$ to $0.15 ; \mathrm{p}=0.030)$.

\section{DISCUSSION}

\section{The Effect of Pregnancy Complica- tions on Maternal Mortality}

The bivariate analysis results showed that maternal pregnancy complications affected maternal mortality. Pregnancy complications have a risk of experiencing maternal death 7.62 times greater when compared to women who did not experience pregnancy complications $(\mathrm{OR}=7.62 ; 95 \% \mathrm{CI}=3.35$ to $17.31 ; \mathrm{p}$ $<0.001)$. This study's results are in line with a study conducted by Kusnadi et al. (2019), which stated that those pregnancy complications have a risk level of 6.98 times, Nababan et al. (2019) stated that have a risk level of 4.2 times. Pregnancy complications have a risk of maternal death by 25.50 times (Respati et al., 2018).

In this study, pregnancy complications included severe preeclampsia, preeclampsia, eclampsia, and pulmonary edema. Preeclampsia is a multisystemic disease characterized by significant gestational hypertension and proteinuria since the second half of pregnancy in women who were previously normotensive and proteinuric (Ragasudha et al., 2018). On the other hand, Eclampsia is an extreme spectrum of preeclampsia, defined as new attacks of tonic seizures. -General clone during pregnancy or the puerperium in patients with preeclamptic characteristics (Ajah, 2016). Worldwide, preeclampsia is estimated to complicate about $2-10 \%$ of pregnancies. The incidence is estimated to be seven times higher in developing countries (2.8\% live births) than in developed countries, $0.4 \%$ of live births. Severe preeclampsia accounts for more than 63,000 maternal deaths every year, with about $98 \%$ of these deaths occurring in developing countries (Onoh et al., 2019).

The results of this study also included maternal patients caused by heart and pulmonary edema. Pregnant patients with uncorrected heart disease increased maternal mortality by $10.7 \%$, and those with heart disease and pulmonary edema increased maternal mortality by $12.5 \%$. The worsening outcome in pregnancy and childbirth of pregnant patients with heart disease and pulmonary edema is largely caused by a compromised cardiovascular system and worsening breathing (Hartopo et al., 2019).

\section{The Effect of Delivery Complications on Maternal Mortality}

The bivariate analysis results showed that mothers who had delivery complications had a risk of experiencing maternal death 5.886 times greater than those who did not experience labor complications, with a p-value <0.001 (adjusted OR = 5.886; 95\% CI: 2.506 - 13.829). The results of this study are in accordance with a previous study which stated that delivery complications have a risk of maternal death by 10.0 times (Taufiq et al., 2018), a risk level of maternal death by 7.59 times (Kusnadi et al., 2019), and a level of risk 9.53 times (Nababan et al., 2019).

In this study, the delivery complications were embolism, atony, postpartum hemorrhage, eclampsia, and thyroid storm, contributing to maternal mortality. Pregnant women with embolism are more likely to have heart attacks and are more likely to have a given platelet or concentrated fibrinogen (Fitzpatrick et al., 2019). The proportion of maternal deaths caused by embolism increased to $12.5 \%$ (Mu et al., 2016). Embolism is a rare pregnancy complication with relatively high mortality (McDonnell et al., 2013). Embolism also accounts for $15.70 \%$ of maternal mortality in Hunan province, the time from the onset of episodes of amniotic 
fluid embolism to death mostly occurring in 2 the first hour (Lili et al., 2018).

Apart from embolism, maternal mortality is also caused by postpartum hemorrhage. Primary postpartum hemorrhage is the leading cause of maternal death worldwide. Mothers who experience hemorrhage postpartum complications have 6.8 times the risk of experiencing maternal death (Kebede et al., 2019). Incidence of atonic PPH o.88\%. Atonic PPH is more common in cesarean delivery compared to vaginal delivery (Butwick et al., 2017). In this study, maternal mortality was caused by thyroid storm, and hyperthyroidism during pregnancy was rare. However, if it is not resolved during pregnancy, it will cause harm to the mother and fetus because uncontrolled thyrotoxicosis significantly increases the risk of maternal and fetal complications (Moleti et al., 2019).

\section{The Effect of Postpartum Complica- tions on Maternal Mortality}

The bivariate analysis results showed that mothers who had postpartum complications had a risk of experiencing maternal death 16.97 times greater than those who did not experience postpartum complications (OR= 16.97; $95 \% \mathrm{CI}=5.75$ to 50.13 ; $\mathrm{p}<0.001$ ). This study's results are in accordance with the study that has been done, which stated that those women who have postpartum complications are 2.10 times more at risk (Taufiq et al., 2018). Postpartum complications in this study, namely eclampsia, preeclampsia, severe preeclampsia, peritonitis, bleeding, atony, baby blues, asthma, and heart disease, contribute to maternal death.

Postpartum complications have a high risk of maternal death. The existence of complications during the puerperium, especially bleeding during the puerperium, can lead to maternal death, especially if the mother does not immediately receive initial treatment to control bleeding (Halder et al., 2015). Maternal mortality in this study was also caused by peritonitis. This study is according to a study that stated that $3 \%$ of maternal deaths were caused by postpartum peritonitis or postabortion (Hounkpatin and Obossou, 2016). Peritonitis, especially due to cesarean delivery, significantly affects morbidity and mortality (Rwabizi et al., 2016).

\section{The Effect of ANC Examination on Maternal Mortality}

The statistical analysis results showed that mothers whose number of ANC <4 times have a risk factor of maternal mortality $(\mathrm{OR}=$ 8.72; 95\% CI $=0.94$ to $80.58 ; \mathrm{p}=0.024$ ). This means that mothers who undergo ANC $<4$ times are more likely to have an $\mathbf{8 . 7 2}$ times higher risk of experiencing maternal death. This study's results are in accordance with a study conducted by Oyerinde (2013) and Bauserman et al. (2015), which stated that the lack of antenatal care visits has the risk of maternal death 1.8 times. Yego et al. (2014) stated that mothers without antenatal care visits risk maternal mortality by 4.1 times.

In theory, antenatal care can reduce maternal morbidity and mortality directly through the detection and treatment of pregnancy-related illnesses or complications, or indirectly by detecting women who are at higher risk of delivery complications and ensuring that mothers deliver in appropriate facilities. However, the potential for realizable antenatal interventions to address this problem is unclear for several reasons. Most of the formal investigations regarding the effectiveness of antenatal care programs, whether in developed or developing countries, have concentrated on the effects of treatment on infant outcomes, perinatal mortality, preterm birth, and low birth weight (Carroli et al., 2001).

Not having adequate antenatal care during pregnancy results in mortality. Antenatal care plays an important role in screening for pre-existing diseases and complications in the early stages of pregnancy that can 
adversely affect pregnancy and delivery. A good ANC should have at least four visits during pregnancy, as recommended by international organizations (Yego et al., 2014).

\section{The Effect of Delay in Making Deci- sions on Maternal Mortality}

The statistical analysis results showed that delay in making decisions had a risk factor for maternal death by 50.37 times $(\mathrm{OR}=$ 50.37; $95 \% \mathrm{CI}=6.38$ to $397.65 ; \mathrm{p}<0.001)$. This means that delay in making decisions is the highest risk factor for maternal death. This fatality often occurs because there is a factor of delay in decision making in the family. It is not uncommon for advice given by friends or neighbors to influence decisions taken. Delays in making decisions are due to patrilinear culture, where the husband has an important role in making the wife's referral decision (Bata \& Emilia, 2019).

The proportion of maternal mortality due to delay in making decisions has a $14.9 \%$ (Mgawadere et al., 2017). 75\% of Haiti's maternal deaths are due to delay in making decisions (Barnes-Josiah et al., 1998). Delays in decision-making at the community level can be caused by several things, such as problems with tradition or trust in decision making in the family, financial incapacity, late family referral because they do not understand the danger signs that threaten the mother's life, health workers are late in preventing and identifying complications early on. Health workers cannot advocate for patients and their families about the importance of referring on time so that mothers and infants are safe (Kemenkes RI, 2013).

\section{The Effect of Delay in the Referral on Maternal Mortality}

The statistical analysis results showed that late referral affected maternal mortality. This study's results are consistent with a study conducted by Aeni (2013), which stated that late referral has the risk of maternal death. The referral system, especially in emergency obstetric care, must be done appropriately. The results showed that more than $75 \%$ of mothers with complications had made referrals when complications occurred in both the case and control groups. So it can be seen that the referral system has been running. However, it must be seen further whether there are three delays in implementing the referral (Kemenkes RI, 2013).

The results showed that most people were not late in referring, because in general, the problems in reaching the referral location were geographic, transportation availability, stabilization of complicated or ineffective patients, as well as patient monitoring as long as the referral was not carried out or carried out but was not followed up (Kemenkes RI, 2013). In this study, the referral needed by the mother was from one health facility to another because of the lack of emergency transportation.

\section{The Effect of Education on Mater- nal Mortality}

The results of statistical analysis showed that low education was a risk factor for maternal death $(\mathrm{OR}=5.43$; 95\% CI: 1.197-24.60; $\mathrm{p}=$ 0.016). This means that mothers with low education experience maternal mortality by 5.426 times greater. The level of education of a mother affects the level of knowledge about the dangers of pregnancy risks. High knowledge implies that respondents can provide sufficient information about the causes and risk factors for maternal death. Meanwhile, low knowledge implies that respondents can provide little or no information about maternal death's causes and risk factors (Amoo \& Ajayi, 2019).

This study is in accordance with other studies, which also state that the risk of death is higher among women with low education. These findings emphasize the importance of education for mothers and their partners to obtain and understand the benefits of good health and to be able to make the right de- 
cisions during pregnancy (Yego et al., 2014). Low maternal education results in a lack of knowledge about reproductive health and the rights that must be obtained during pregnancy not to be aware of risky pregnancies (Begum et al., 2003).

A study conducted by (Bomela, 2020) also showed that the majority of deaths occurred among those with a low educational status by $46.2 \%$ and higher than mothers with higher educational status. This is in line with a study conducted by Bausserman's, which stated that people who do not go to school have the risk by 3.2 times. People with primary education are 3.4 times more at risk, and people with secondary education are 2.5 times at risk (Bauserman et al., 2015).

\section{The Effect of Income on Maternal Mortality}

The results of statistical analysis showed that family income below the minimum wage was a risk factor for maternal death ( $\mathrm{p}<0.001)$ with (OR $=5.443 ; 95 \% \mathrm{CI}: 2.402-12.336)$. This means that families with an income below the minimum wage are 5.44 times more likely to experience maternal death. The low-income group is a risk factor for maternal death. Increase household income and subsidies are likely to provide increased financial access to hospital transfers and thereby reduce delays in seeking care around the time of birth. This suggests that the government must take targeted steps to reduce poverty and provide better access to medical services. This study's results are in accordance with a study by Jeong et al. (2020) which stated that family income under the minimum wage is a risk factor for maternal death. Mothers with low income have a 2.42 times higher risk of maternal mortality within six weeks.

\section{AUTHOR CONTRIBUTION}

Arfan Syahfani Sesunan, Supriyadi Hari Respati, and Sri Sulistyowati collect the data, wrote the original manuscript.

\section{CONFLICT OF INTEREST}

The author stated that this study is conducted without any correlation with financial or commercial factors, which can be interpreted as a conflict of interest.

\section{FUNDING AND SPONSORSHIP}

This study used the authors' funds.

\section{ACKNOWLEDGEMENT}

The authors would like to express their gratitude all health care staffs, cadres, and mothers who participated in this study, as well as to the Development Planning Agency at Sub-National Level in Klaten and the Klaten Health Office for giving a permission so that this study can be carried out.

\section{REFERENCE}

Aeni, Nurul., (2013). Faktor Risiko Kematian maternal.Jurnal Kesehatan Masyarakat Nasional. 7(10): 453-59.

Ahmed S, Fullerton J (2019). Challenges of reducing maternal and neonatal mortality in Indonesia: Ways forward. Int $\mathrm{J}$ Gynecol Obstet. 144(1): 1-3. https://doi.org/10.1002/ijgo.12728.

Ajah LO, Ozonu NC, Ezeonu PO, Lawani LO, Obuna JA, Onwe EO (2016). The fetomaternal outcome of preeclampsia with severe features and eclampsia in Abakaliki, South-East Nigeria. J Clin Diagn Res. 10(9): QC18-QC21. https://doi.org/10.7860/jcdr/2016/21078.8499.

Barnes-Josiah D, Myntti C, Augustin A (1998). The "three delays" as a framework for examining maternal mortality in Haiti. Soc Sci Med. 46(8): 981-993. https://doi.org/10.1016/s0277-9536(97)10018-1 
Bata VA, Emilia O (2019). Peran pengambil keputusan dalam keterlambatan rujukan maternal. Berita Kedokteran Masyarakat, 4(1), 7. https://doi.org/10.22146/bkm.37716

Bauserman M, Lokangaka A, Thorsten V, Tshefu A, Goudar SS, Esamai F, Garces A, et al. (2015). Risk factors for maternal death and trends in maternal mortality in low- and middle-income countries: a prospective longitudinal cohort analysis. Reprod Health. 12(2): S5. https://doi.org/10.1186/1742-475512-s2-s5.

Begum S, Nisa A, Begum I (2003). Analysis of maternal mortality in a tertiary care hospital to determine causes and preventable factors. J Ayub Med Coll Abbottabad. 15(2): 49-52. PMID: 14552250.

Bomela NJ (2020). Maternal mortality by socio-demographic characteristics and cause of death in South Africa: 20072015. BMC Public Health. 20(1):157. https://doi.org/10.1186/s12889-0208179-x.

Butwick AJ, Ramachandran B, Hegde P, Riley ET, El-Sayed YY, Nelson LM (2017). Risk factors for severe postpartum hemorrhage after cesarean delivery: Case-control studies. Anesth Analg. 125(2): 523-532. https://dx.doi.org/10.1213\%2FANE.ooooooooo0001962.

Carroli G, Rooney C, Villar J (2001). How effective is antenatal care in preventing maternal mortality and serious morbidity? An overview of the evidence. Paediatr Perinat Epidemiol, 15(1): 1-42. https://doi.org/10.1046/j.1365-3016.2001.0150s1001.x.

Depkes Jateng, (2018). Profil Kesehatan Jawa Tengah Tahun 2018.

Fitzpatrick KE, van den Akker T, Bloemenkamp KWM, Deneux-Tharaux C, Kris- tufkova A, Li Z, Schaap TP, Sullivan EA, Tuffnell, D, Knight M (2019). Risk factors, management, and outcomes of amniotic fluid embolism: A multicountry, population-based cohort, and nested Kasus-Kontrol study. PLOS Medicine, 16(11), e1002962.https://doi.org/10.1371/journal.pmed.1002962

Halder A, Jose R, Vijayselvi R (2014). Maternal mortality and derivations from the WHO near-miss tool: An institutional experience over a decade in Southern India. J Turk Ger Gynecol Assoc. 15(4): 222-227. https://dx.doi.org/10.5152\%2Fjtgga.2014.14076.

Hartopo AB, Anggrahini DW, Nurdiati DS, Emoto N Dinarti LK (2019). Severe pulmonary hypertension and reduced right ventricle systolic function associated with maternal mortality in pregnant uncorrected congenital heart diseases. Pulmonary Circulation. 9(4): 1-9. DOI: $10.1177 / 2045894019884516$.

Hounkpatin B, Obossou AAA, Aguemon CT, Hounkponou FN, Aboubakar M, Sehlouan C, Tonato-Bagnan A, Perrin RX (2016). The impact of audits of maternal deaths and near miss at University Hospital of Mother and Child Lagoon (Benin). Clinics Mother Child Health. 13(1): 218. https://dx.doi.org/10.4172/2090-7214.1000218.

Jeong W, Jang SI, Park EC, Nam JY (2020). The Effect of socioeconomic status on all-cause maternal mortality: A nationwide population-based cohort study. Int J Environ Res Public Health. 17(12): 4606. https://doi.org/10.3390/ijerph$17124606 /$.

Kebede BA, Abdo RA, Anshebo AA, Gebremariam BM (2019). Prevalence and predictors of primary postpartum hemorrhage: An implication for designing effective intervention at selected hospitals, Southern Ethiopia. PLOS ONE, 
14(10): e0224579. https://doi.org/10.1371/journal.pone.0224579.

Kemenkes RI (2013). Riset Kesehatan Dasar. Jakarta: Badan Penelitian dan pengembangan Kesehatan Kementrian Keseha$\tan$ RI.

Koyejo Oyerinde K (2013). Can antenatal care result in significant maternal mortality reduction in developing countries?. J Community Med Health Educ. 3:1. http://dx.doi.org/10.4172/2161-0711.1000e116.

Kusnadi N, Respati SH, Sulistyowati S (2019). Risk Factors of Maternal Death in Karanganyar, Central Java, Indonesia. J Matern Child Health. 4(6): 499-506. https://doi.org/10.26911/thejmch.2019 .04.06.10.

Lili X, Jian H, Mengjun Z Yinglan W, Donghua X, Aihua W, Fanjuan K, et al. (2018). Epidemiological analysis of maternal deaths in Hunan province in China between 2009 and 2014. PLoS One. 13(11): eo207920. https://dx.doi.org/10.1371\%2Fjournal.pone.0207920.

McDonnell NJ, Percival V, Paech MJ (2013). Amniotic fluid embolism: a leading cause of maternal death yet still a medical conundrum. Int $\mathrm{J}$ Obstet Anesth. 22(4): 329-36. https://doi.org/10.1016/j.ijoa.2013.08.004.

Mgawadere F, Unkels R, Kazembe A, van den Broek N (2017). Factors associated with maternal mortality in Malawi: Application of the three delays model. BMC Pregnancy Childbirth. 17(1): 219. https://doi.org/10.1186/s12884-017-14o6-5.

Moleti M, Di Mauro M, Sturniolo G, Russo M, Vermiglio F (2019). Hyperthyroidism in the pregnant woman: Maternal and fetal aspects. J Clin Transl Endocrinol. 16: 100190. https://doi.org/10.1016/j.jcte.2019.100190.
Mu Y, McDonnell N, Li Z, Liang J, Wang Y, Zhu J, Sullivan E (2016). Amniotic fluid embolism as a cause of maternal mortality in China between 1996 and 2013: A population-based retrospective study. BMC Preg Childbirth. 16(1): 316. https://doi.org/10.1186/s12884-016-1106-6. Nababan R, Sulistyowati S, Respati SH (2019). Analisis Faktor Determinan Kematian Ibu di Kabupaten Sukoharjo Jawa Tengah Indonesia. Jurnal Kesehatan Reproduksi, 6(2), 52. https://doi.org/$10.22146 / \mathrm{jkr} .43463$

Olonade O, Olawande TI, Alabi OJ, Imhonopi D (2019). Maternal mortality and maternal health care in Nigeria: Implications for socioeconomic development. Open Access Maced J Med Sci. 7(5): 849-855. doi: 10.3889/oamjms.2019.041.

Onoh R, Mamah J, Umeokonkwo C, Onwe E, Ezeonu P, Okafor L (2019). Severe preeclampsia and eclampsia: A 6-year review at the Federal Teaching Hospital, Abakaliki, Southeast NigeriaTrop J Obstet Gynaecol. 36(3): 418. https://doi.org/10.4103/TJOG.TJOG_45_19

Ragasudha C, Madhavi AP, Sharon S, Priya SS, Shehnaz S (2018). A study of maternal deaths from preeclampsia and eclampsia in a tertiary care centre. Int Arch Integr Med. 5(1): 6-10. http://iaimjournal.com/wp-content/uploads/2018/01/iaim_2018_0501_02.pdf.

Respati SH, Taufiq AC, Sulistyowati S (2018). Determinant factors affecting maternal death in Boyolali District. J South Asian Feder Obstet Gynaecol. 10(2): 149-153. https://doi.org/10.5005/jpjournals-10006-1579.

Rwabizi D, Rulisa S, Aidan F, Small M (2016). Maternal near miss and mortality due to postpartum infection: a cross-sectional analysis from Rwanda. BMC Pregnancy Childbirth. 16: 177. 
https://dx.doi.org/10.1186\%2Fs12884016-0951-7.

Sk MIK, Paswan B, Anand A, Mondal NA (2019). Praying until death: revisiting three delays model to contextualize the socio-cultural factors associated with maternal deaths in a region with high prevalence of eclampsia in India. BMC Pregnancy Childbirth. 19(314). https://doi.org/10.1186/s12884-019-2458-5.

Smith SL, Rodriguez MA (2016). Agenda setting for maternal survival: the power of global health networks and norms. Health Policy Plan. 31(1): i48-59. https://doi.org/10.1093/heapol/czu114.

WHO (2011). Unsafe abortion: Global and regional estimates of the incidence of unsafe abortion and associated mortality in 2008. Six Edition. WHO.

WHO (2019a). Maternal Mortality Ratio. Retrieved from https://www.who.int/healthinfo/statistics/indmaternalmorta lity/en/.

WHO (2019b). Maternal Mortality. Retrieved from https://www.who.int/news-room/fact-sheets/detail/maternal-mortality Yego F, D'este C, Byles J, Williams JS, Nyongesa P (2014). Risk factors for maternal mortality in a Tertiary Hospital in Kenya: A case control study. BMC Pregnancy Childbirth. 14: 38. https://doi.org/10.1186/1471-2393-14-38. 